\title{
Pemetaan Objek Wisata Desa Pandanrejo Kota Batu Berbasis Geographic Information System (GIS)
}

\author{
Nila Restu Wardani ${ }^{1 *}$, Achmad Maulana Malik Jamil ${ }^{1}$ \\ ${ }^{1}$ Program Studi Pendidikan Geografi, Universitas Kanjuruhan Malang, Malang 65148, Indonesia \\ Email : *nilarestu@unikama.ac.id, maulana3188@unikama.ac.id
}

Dikirim : 02 September 2020

Diterima: 25 September 2020

\begin{abstract}
Abstrak: Desa Pandanrejo merupakan desa wisata di Kecamatan Bumiaji Kota Wisata Batu. Tujuan penelitian yaitu memetakan sembilan objek wisata menggunakan aplikasi Arc. GIS 3.3. Pemetaan ini berguna untuk memberikan informasi kepada wisatawan tentang data spasial objek dan daya tarik wisata. Metode yang digunakan adalah survei dengan menetukan titik koordinat setiap objek wisata. Selanjutnya titik koordinat dijadikan input data pada aplikasi Arc.GIS 3.3. Pengumpulan data primer dilakukan dengan cara observasi langsung ke objek wisata. Pengumpulan data sekunder meliputi Citra Quickbird Desa Pandanrejo, serta Peta Rupa Bumi Indonesia (RBI). Analisis data dilakukan secara deskriptif. Berdasarkan hasil pemetaan objek wisata di Desa Pandanrejo, maka ada sembilan objek wisata diantaranya: enam objek wisata alam dan tiga objek wisata budaya. Kesembilan objek wisata ini tersebar di empat dusun. Masing-masing objek wisata memiliki daya tarik wisata tersendiri berupa keindahan alam dan keunikan budaya.
\end{abstract}

Kata kunci: pemetaan, objek wisata, Geographic Information System (GIS).

Abstract: Pandanrejo Village is a tourism village in Bumiaji District, Batu Tourism City. The purpose of this study is to map nine tourism destination using the Arc. GIS 3.3 application. This mapping is useful to provide information to tourists about the spatial data of tourism destination. The study used survey method by determining the coordinates of each tourism destination. Furthermore, the coordinates are used as input data in the Arc.GIS 3.3 application. Primary data collection by direct observation to tourism destination. Secondary data collection are the Quickbird Image of Pandanrejo Village, as well as the Rupa Bumi Indonesia(RBI) map. Data analysis was performed descriptively. Based on the results of the mapping of attractions in the village of Pandanrejo, there are nine tourism destination: six natural tourism destination and three cultural tourism destination. These nine attractions are scattered in four hamlets. The tourism destination has its own tourist of natural beauty and cultural uniqueness.

Keywords: mapping, tourism destination, Geographic Information System (GIS). 


\section{Pendahuluan}

Kota Batu merupakan kota pariwisata di Jawa Timur dengan keunikan spasial yaitu berada pada daerah pegunungan. Sebagai kota pariwisata, Kota Batu terus mengalami peningkatan jumlah objek wisata. Jumlah objek wisata di Kota Batu yaitu 25 objek wisata, baik wisata alam dan budaya (BPS, 2017). Objek wisata bentang alam menekankan pada kekhasan kondisi alamiah yang masih murni atau sedikit pengaruh dari manusia. Objek wisata bentang budaya memberikan kekhasan sebagai bentukan antropogenik dalam proses pembentukannya (Santosa dan Muta'ali, 2014).

Perkembangan pariwisata memberikan pengaruh positif terhadap keberadaan desa dan kelurahan di Kota Batu. Desa dan kelurahan di Kota Batu berlomba mengembangkan potensinya menjadi objek wisata, baik wisata alam dan budayannya. Salah satu desa yang saat ini menjadi tujuan wisata yaitu Desa Pandanrejo.

Secara administratif Desa Pandanrejo terletak di Kecamatan Bumiaji. Desa Pandanrejo memiliki potensi lahan pertanian stroberi dan dikembangkan sebagai Desa Wisata Stroberi. Meskipun disebut sebagai Desa Wisata Stroberi, objek wisata yang ada juga bervariasi yaitu: Kampoeng Kidz; Kaliwatu Rafting; Lumbung Stroberi; Pemandian Sumber Dadapan; Kampung Budaya Dadapan; Coban Lanang; Café Ubi; Taman Dolan; River Tubing Kali Jowo.

Pemetaan objek wisata di Desa Pandanrejo perlu dilakukan. Pemetaan ini berguna untuk memberikan informasi kepada wisatawan tentang macam-macam dan lokasi objek wisata. Pemetaan obek wisata bisa dilakukan dengan Geographic Information System (GIS) atau Sistem Informasi Geografi (SIG). GIS merupakan alat untuk membuat peta, menganalisis data, serta melaporkan hasilnya (ESRI, 2012). GIS mampu menyajikan fenomena dunia nyata salah satunya pemetaan objek wisata secara digital. Dibandingkan dengan peta pada lembaran kertas, GIS memberikan tampilan yang lebih menarik.

Gunn dan Larsen (1988) dalam Riwayatiningsih dan Purnaweni (2017) menyatakan bahwa penggunaan GIS dalam pemetaan pariwisata masih sangat sedikit dilakukan meskipun teknologi GIS telah dibahas dalam literatur pariwisata lebih dari satu dekade terakhir. Teknologi ini telah digunakan dalam penelitian yang berhubungan dengan perencanaan ekowisata, penilaian sumber daya visual dan manajemen, identifikasi lokasi yang cocok, dan penggunaan aplikasi yang berkaitan dengan pemasaran pariwisata (Riwayatiningsih dan Purnaweni, 2017).

Pariwisata di Desa Pandanrejo membutuhkan aplikasi GIS untuk memetakan informasi objek wisata sebagai langkah awal untuk perencanaan. Bidang pariwisata dan fungsi GIS saling berhubungan (Bahaire dan Elliot-White, 1999). GIS mampu menghubungkan berbagai data objek wisata di Desa Pandanrejo. Selanjutnya GIS menggabungkan, menganalisis, dan memetakan objek wisata sebagai keluarannya, serta dapat memberikan informasi spasial objek wisata dengan berbagai daya tarik wisata yang ada.

Pemberian informasi pada wisatawan pada era teknologi saat ini menjadi sesuatu yang penting. Perkembangan teknologi telah mendorong penyampaian informasi spasial menjadi lebih interaktif (Hamdani, 2016). Oleh karenanya pemetaan objek wisata di Desa Pandanrejo dengan bantuan GIS menjadi penting untuk dilakukan. 


\section{Metode Penelitian}

Penelitian ini dilakukan di Desa Pandanrejo Kecamatan Bumiaji Kota Batu. Pendekatan penelitian yaitu kualitatif dengan metode survei. Survei dilakukan di semua objek wisata di desa ini. Jumlah objek wisata ada Sembilan, yaitu: 1) Kampoeng Kidz; 2) Kaliwatu Rafting; 3) Lumbung Stroberi; 4) Pemandian Sumber Dadapan; 5) Kampung Budaya Dadapan; 6) Coban Lanang; 7) Café Ubi; 8) Taman Dolan; 9) River Tubing Kali Jowo.

\section{Pengumpulan data}

1. Pengumpulan data dilakukan dengan observasi untuk mengambil data primer di lapangan, meliputi: titik koordinat; karakteristik bentang alam; daya tarik wisata; aksesibilitas menuju objek wisata; transportasi penghubung

2. Pengumpulan dokumentasi meliputi Citra Quickbird dan Peta Rupa Bumi Indonesia yang diproses menggunakan aplikasi Arc.GIS 3.3.

3. Global Position System (GPS) digunakan untuk menentukan titik koordinat objek wisata.

\section{Analisis data}

Data yang diperoleh dijadikan input data pembuatan peta persebaran objek wisata (wisata alam dan budaya) dengan software Arc. GIS 3.3. Data yang dibutuhkan yaitu koordinat lokasi objek wisata. Koordianat lokasi diperoleh dari penentuan titik menggunakan Global Positition System (GPS). Setelah peta persebaran objek wisata Desa Pandanrejo dibuat selanjutnya dianalisis secara deskripstif karaksteristik objek wisata.

\section{Hasil Penelitian}

Objek wisata di Desa Pandanrejo berupa objek wisata alam dan budaya. Berikut ini hasil penentuan koordinat lokasi objek wisata.

Tabel 1. Koordinat Lokasi Objek Wisata di Desa Pandanrejo

\begin{tabular}{|c|c|c|c|c|c|}
\hline \multirow{2}{*}{ No } & \multirow{2}{*}{$\begin{array}{c}\text { Nama Objek } \\
\text { Wisata }\end{array}$} & \multicolumn{2}{|c|}{ Koordinat } & \multirow{2}{*}{ Dusun } & \multirow{2}{*}{$\begin{array}{c}\text { Jenis } \\
\text { Objek Wisata }\end{array}$} \\
\hline & & $\mathbf{S}$ & $\mathbf{E}$ & & \\
\hline 1 & Kampoeng Kidz & $07^{\circ} 51.807^{\prime}$ & $112^{\circ} 31.983^{\prime}$ & Kajar & Budaya \\
\hline 2 & Kaliwatu Rafting & $07^{\circ} 51.831^{\prime}$ & $112^{\circ} 32.070^{\prime}$ & Kajar & Alam \\
\hline 3 & Lumbung Stroberi & $07^{\circ} 52.117^{\prime}$ & $112^{\circ} 32.526^{\prime}$ & Pandan & Alam \\
\hline 4 & $\begin{array}{l}\text { Pemandian Sumber } \\
\text { Dadapan }\end{array}$ & $07^{\circ} 51.992^{\prime}$ & $112^{\circ} 32.638^{\prime}$ & Dadapan & Alam \\
\hline 5 & $\begin{array}{l}\text { Kampung Budaya } \\
\text { Dadapan }\end{array}$ & $07^{\circ} 51.934^{\prime}$ & $112^{\circ} 32.682^{\prime}$ & Dadapan & Budaya \\
\hline 6 & Coban Lanang & $07^{\circ} 52.222^{\prime}$ & $112^{\circ} 33.087^{\prime}$ & Ngujung & Alam \\
\hline 7 & Café Ubi & $07^{\circ} 52.099^{\prime}$ & $112^{\circ} 33.132^{\prime}$ & Ngujung & Budaya \\
\hline 8 & Taman Dolan & $07^{\circ} 51.834^{\prime}$ & $112^{\circ} 33.244^{\prime}$ & Ngujung & Alam \\
\hline 9 & $\begin{array}{l}\text { River Tubing Kali } \\
\text { Jowo }\end{array}$ & $07^{\circ} 52.092^{\prime}$ & $112^{\circ} 33.022^{\prime}$ & Ngujung & Alam \\
\hline
\end{tabular}

Sumber: Hasil Penelitian (2019) 
Berdasarkan tabel 1 diketahui bahwa Desa Pandanrejo terdiri dari 4 dusun, yaitu : Dusun Kajar, Dusun Pandan, Dusun Dadapan, dan Dusun Ngujung. Desa Pandanrejo memiliki 9 objek wisata yang terdiri dari 6 objek wisata alam dan 3 objek wisata budaya. 6 objek wisata alam yaitu: Kaliwatu Rafting; Lumbung Stroberi; Pemandian Sumber Dadapan; Coban Lanang; Taman Dolan; River Tubing Kali Jowo.3 objek wisata budaya yaitu: Kampoeng Kidz; Kampung Budaya Dadapan; Café Ubi.

Letak astronomis berdasarkan titik koordinat setiap objek wisata tidak jauh dan mudah dijangkau dari jalam raya. Titik koordinat ini menjadi dasar pemetaan objek wisata. Berikut ini Peta Objek Wisata Desa Pandanrejo. 


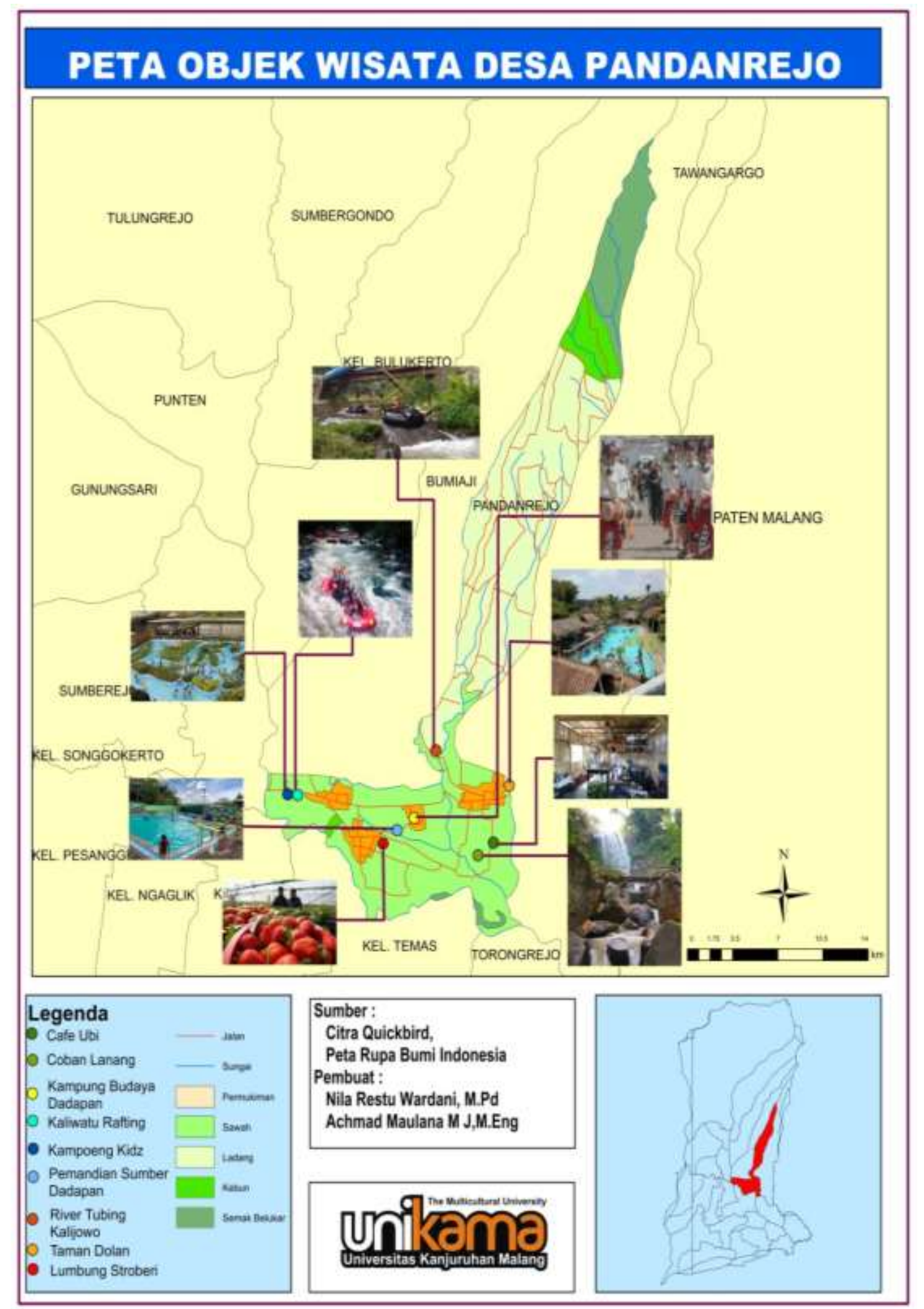

Gambar 1 Peta Objek Wisata Desa Pandanrejo Kota Batu

\section{Pembahasan}

Desa Pandanrejo terletak di Kecamatan Bumiaji Kota Batu. Desa Pandarejo terletak pada ketinggian $700-800 \mathrm{~m}$ dpl. Suhu udara optimum berkisar $15-25^{\circ} \mathrm{C}$ dan suhu minimum 
berkisar $3-5^{0} \mathrm{C}$. Desa ini memiliki kelembaban udara $85-91 \%$ dengan lama peyinaran matahari 7,9-9,5 jam/hari. Curah hujan Desa Pandanrejo antara 500-900 mm/tahun.

Desa Pandanrejo merupakan desa wisata yang dikembangkan sesuai potensi alam dan budayanya. Berikut ini deskripsi objek wisata di Desa Pandanrejo.

\section{Kampoeng $K i d z$}

Kampoeng Kidz secara geografis terletak di sebelah barat Desa Pandanrejo tepatnya di Dusun Kajar. Kampoeng Kidz berada pada titik 0751.807'LS dan 112 $31.983^{\prime}$ BT. Kampoeng Kidz bisa dijangkau dengan mudah oleh wisatawan karena letaknya di tepi jalan raya. Alat transportasi bisa dengan mudah menjangkau, diantaranya: sepeda motor; mobil, elf, bus kecil, hingga bus besar. Kemudahan akses ini mendukung kemajuan Kampoeng Kidz. Aksesbilitas sangat berperan penting karena untuk menjangkau suatu obyek wisata diperlukan suatu sistem transportasi yang dapat mendukung keberadaan suatu objek dan daya tarik wisata tersebut dan juga memberikan kemudahan bagi para wisatawan yang hendak mengunjungi objek wisata tersebut (Damanik, dkk, 2006).

Kampoeng Kidz merupakan wisata budaya karena wisatawan bisa merasakan kehidupan dan kebudayaan masyarakat pedesaaan. Hal ini sesuai dengan pernyataan Pendit (1994) yaitu wisata budaya merupakan perjalanan wisata ke tempat lain atau ke luar negeri yang dilakukan dengan maksud untuk mengetahui dan mempelajari keadaan rakyat, kebiasaan dan ada istiadat, cara hidup budaya dan seni masyarakat di lokasi yang dituju. Kampoeng Kidz menyajikan suasana kehidupan pedesaan melalui berbagai macam aktfitas seperti outbound, belajar menanam, belajar memanen, belajar memberi makan merpati, belajar cara memegang kelinci, dan belajar bermacam-macam pengetahuan tentang ternak. Fasilitas lain yaitu Holiday Camp bagi wisatawan yang ingin merasakan suasana pedesaan selama musim liburan.

\section{Kaliwatu Rafting}

Kaliwatu Rafting terletak di Dusun Kajar dengan titik koordinat $07^{\circ} 51.831^{\prime} L S$ dan $112^{\circ} 32.070 ' B T$. Kaliwatu Rafting termasuk dalam wisata alam karena aktivitas wisata yang dilakukan yakni arum jeram menyusuri Sungai Brantas yang melewati Dusun Kajar dan Dusun Pandan. Keempat dusun di Desa Pandanrejo dilalui aliran Sungai Brantas. Aliran sungai yang deras dengan susunan batuan beku yang ada di sepanjang sungai menjadi daya tarik wisata saat melakukan arum jeram. Lintasan arum jeram sepanjang $7 \mathrm{~km}$ ini biasanya ditempuh selama 1,5 jam.

\section{Lumbung Stroberi}

Objek wisata Lumbung Stroberi berada di Dusun Pandan dengan titik koordinat $07^{\circ} 52.117^{\prime} \mathrm{LS}$ dan $112^{\circ} 32.526^{\prime} \mathrm{BT}$. Lumbung Stroberi termasuk objek wisata alam karena dikembangkan berdasarkan potensi alamnya yaitu tanaman stroberi yang menjadi tanaman utama dan dibudidayakan oleh masyarakat Dusun Pandan. Hal ini sesuai pernyataan Hadiwijoyo (2012) yaitu objek wisata alam adalah sumberdaya alam yang berpotensi serta memiliki daya tarik bagi pengunjung baik dalam keadaan alami maupun setelah ada usaha budi daya.

Tanaman stroberi menjadi daya tarik tersendiri bagi wisatawan untuk melakukan petik stroberi. Wisatawan bisa memetik secara langsung buah stroberi di lahan. Selain itu juga ada edukasi penanaman bibit stroberi, cara perawatan, hingga pengolahan hasil buah stroberi. Akses jalan menuju Lumbung Stroberi terbatas hanya kendaraan sepeda motor, mobil, elf, dan bus kecil. Wisatawan yang berkunjung dengan bus besar maka harus berhenti di rest area selanjutnya naik kendaraan seatle ke Lumbung Stroberi. 


\section{Pemandian Sumber Air Dadapan}

Pemandian Sumber Air Dadapan terletak di Dusun Dadapan dan berjarak $600 \mathrm{~m}$ dari jalan raya. Titik koordinatnya berada pada $07^{\circ} 51.992^{\prime} \mathrm{LS}$ dan $112^{\circ} 32.638^{\prime} \mathrm{BT}$. Objek wisata ini termasuk objek wisata alam karena memanfaatkan sumber air yang ada. Kolam renang dibangun untuk memberikan fasilitas pemandian yang lebih menarik karena pemandian ini masih menjadi tujuan masyarakat lokal Desa Pandanrejo dan sekitar wilayah Kota Batu.

\section{Kampung Budaya Dadapan}

Kampung Budaya Dadapan terletak di Dusun Dadapan. Titik koordinatnya berada pada $07^{\circ} 51.934^{\prime} \mathrm{LS}$ dan $112^{\circ} 32.682^{\prime} \mathrm{BT}$. Kampung budaya ini menyajikan atraksi budaya berupa Kentrung dan pemainan tradisional egrang. Atraksi budaya inilah yang menjadikan objek wisata ini termasuk dalam objek wisata budaya.

Atraksi Kentrung dan egrang menjadi daya tarik wisata karena merupakan kesenian daerah yang masih dilestarikan dengan menampilkan di berbagai event dan perlombaan. Nurhaliza (2017) menyatakan bahwa wisata budaya ini merupakan perjalanan yang dilakukan atas dasar untuk mempelajari kebiasaan adat istiadat, mempelajari cara hidup, mempelajari budaya dan juga seni masyarakat yang menjadi tujuan wisata. Daya tarik wisata ini merupakan bagian dari kebiasaan dan kesenian masyarakat Dusun Dadapan.

\section{Coban Lanang}

Coban Lanang terletak di Dusun Ngujung dengan titik koordinat $07^{\circ} 52.222^{\prime} \mathrm{LS}$ dan $112^{\circ} 33.087^{\prime} B T$. Aksesibilitas menuju Coban Lanang dinilai masih sulit karena melewati jalan makadam persawahan dan jembatan terbuat dari bambu. Jarak dari jalan raya $1,5 \mathrm{~km}$ dan yang dapat dilewati mobil dan motor hanya $400 \mathrm{~m}$. Coban Lanang memiliki daya tarik yaitu adanya air terjun di perkotaan, sedangkan pada umumnya air terjun berada di sekitar hutan.

Coban Lanang secara geologis termasuk dalam formasi batuan Gunung Api Arjuno. Coban Lanang berada pada daerah Kecamatan Bumiaji dan kecamatan ini berada pada lereng Gunung Api Arjuno. Materi penyusun gunung Arjuno berupa formasi geologi batuan beku intrusi, sehingga mata air keluar dari celah-celah batuan yang kedap air (impermeable) termasuk dalam fracture spring. Bentuk rekahan-rekahan antar batuan ini mempunyai simpanan air (storage) relatif besar sehingga debit mata air mengalir sepanjang tahun dan relatif besar (Taryana, 2015).

\section{Café Ubi}

Café Ubi terletak di Dusun Ngujung dengan titik koordinat 0752.099'LS dan $112^{\circ} 33.132$ 'BT. Café Ubi berada di tengah sawah dan aksesibititas menuju lokasi ini sangat mudah karena jarak dari tepi jalan raya hanya $350 \mathrm{~m}$ dan bisa dilalui motor dan mobil. Café Ubi memiliki daya tarik menu makanan yang disajikan berupa polo pendem. Polo pendem merupakan jenis tumbuhan yang hasil berupa buah yang terpendam di dalam tanah seperti umbi-umbian: singkong; ubi; kacang tanah. Daya tarik yang lain yaitu polo pendem dimasak di atas tungku api yang disebut pawon.

Café Ubi termasuk dalam wisata budaya karena wisatawan yang mengunjungi objek wisata di Desa Pandanrejo bisa menikmati makanan tradisional masyarakat setempat dengan cara memasak sesuai adat istiadat masyarakat setempat. Hal ini sesuai dengan pernyataan Yoeti (1996) bahwa wisata berbasis budaya adalah salah satu jenis kegiatan pariwisata yang menggunakan kebudayaan sebagai objeknya. Café Ubi menyajikan bentuk kearifan lokal yang dimiliki Desa Pandanrejo berkaitan dengan makanan. 


\section{Taman Dolan}

Taman Dolan terletak di Dusun Ngujung dengan titik koordinat $07^{\circ} 51.834^{\prime} \mathrm{LS}$ dan $112^{\circ} 33.244^{\prime B T}$. Taman Dolan termasuk objek wisata alam yang berada di tepi jalan raya, sehingga sangat mudah dikunjungi. Namun, yang menjadi permasalahan yaitu lahan parkir kurang luas. Taman Dolan memiliki daya tarik sebagai objek wisata pedesaan. Kolam renang menjadi daya tarik tersendiri karena air berasal dari sumber mata air yang dekat dengan lokasi objek wisata. Café bernuansa pedesaan lengkap dengan menu pedesaan. Penginapan yang ada berada di tengah persawahan selada air. Edukasi, outbond, dan river tubing (susur sungai) juga menjadi daya tarik di Taman Dolan.

\section{River Tubing Kali Jowo}

River Tubing Kali Jowo terletak di Dusun Ngujung dengan titik koordinat $07^{\circ} 52.092^{\prime} \mathrm{LS}$ dan $112^{\circ} 33.022^{\prime} \mathrm{BT}$. River tubing merupakan aktivitas susur sungai menggunakan ban ini memanfaatkan potensi sungai yang melewati Dusun Ngujung yaitu Kali Jowo. Hulu Kali Jowo berada di Desa Bumiaji tepatnya di sebelah barat daya Dusun Ngujung. Potensi aliran sungai yang deras namun tidak ekstrem dijadikan sebagai lintasan tubing.

Objek wisata alam dan budaya di Desa Pandanrejo berkembang secara signifikan selama 5 tahun terkahir. Perkembangan ini dikarenakan kemampuan masyarakat sekitar dalam memanfaatkan potensi alam dan budaya yang ada untuk dijadikan sebagai objek wisata. Setiap objek wisata memiliki daya tarik wisata masing-masing.

Pemerintah Desa Pandanrejo memiliki Badan Usaha Milik Desa (Bumdes) Raharjo. Bumdes Raharjo mengelola unit usaha pariwisata Lumbung Stroberi. Lumbung Stroberi menjadi penghubung kerjasama antar objek wisata di Desa Pandanrejo. Kerjasama yang sudah dilakukan yaitu antara Lumbung Stroberi dengan Kaliwatu Rafting, Pemandian Sumber Dadapan, Kampung Budaya Dadapan, Coban Lanang, dan River Tubing Kali Jowo. Bentuk kerjasama berupa paket wisata (petik stroberi, adventure, outbond, gathering, dan edukasi).

Pengelolaan objek wisata di Desa Pandanrejo kedepannya diharapkan bisa terintegrasi sehingga memberikan manfaat bagi kesejahteraan masyarakat dan berkembang menjadi pariwisata berwawasan lingkungan.

\section{Kesimpulan}

Berdasarkan hasil pemetaan objek wisata di Desa Pandanrejo, maka ada sembilan objek wisata diantaranya: enam objek wisata alam dan tiga objek wisata budaya. Kesembilan objek wisata ini tersebar di empat dusun. Masing-masing objek wisata memiliki daya tarik wisata tersendiri berupa keindahan alam dan keunikan budaya. Daya tarik wisata inlah yang menjadikan masyarakat setempat mengembangkan Desa Pandanrejo sebagai Desa Wisata.

\section{Ucapan Terimakasih}

Ucapan terimakasih ditujukan kepada: Lembaga Penelitian dan Pengabdian Universitas Kanjuruhan Malang yang telah mendanai penelitian hingga terpublikasinya artikel ini; Pemerintah Desa Pandanrejo dan Badan Usaha Milik Desa (Bumdes) Raharjo sebagai salah satu pengelola objek wisata di Desa Pandanrejo. 


\section{Daftar Rujukan}

Bahaire, T. \& Elliott-White, M.1999. The Application of Geographical Information Systems (GIS) in Sustainable Tourism Planning: A review. International Journal of Sustainable Tourism, 7 (2), 159-174.

BPS. 2017. Kota Batu Dalam Angka 2017. Batu: Badan Pusat Statistik.

Damanik, Junianton dan Weber, Helmut. 2016. Perencanaan Ekowisata Dari Teori ke Aplikasi. Yogyakarta: PUSPAR UGM dan Andi.

Damayanti, S.N. dan R. Suprihardjo. 2016. Pembentukan Cluster Objek Daya Tarik Wisata. Jurnal Teknik ITS Vol. 5, No 1, 2016.

ESRI. 2012. Quick Start Guide to ArcGIS Online. New York: ESRI.

Gunn, C.A. 1994. Tourism Planning (3rd ed). New York: Taylor and Francis.

Hadiwijoyo, S.S. 2012. Perencanaan Pariwisata Perdesaan Berbasis Masyarakat. Yogyakarta: Graha Ilmu.

Hamdani, A.F dan A.M.M. Jamil, 2016. Sistem Informasi Geografis (Konsep Dasar dan Perkembangan Aplikasinya). Malang: Ediide Infografika.

Holden, A. 2000. Environment and Tourism. London and New York: Routledge.

Nasution, S., Nasution, M. A., \& Damanik, J. 2009 Persepsi Wisatawan Mancanegara Terhadap Kualitas Objek Dan Daya Tarik Wisata (ODTW) Sumatera Utara.

Nurhaliza, Nadya. 2017. Jenis-jenis Objek Wisata Alam yang Perlu Anda Ketahui, (Onlnie) (http://alimustikasari.com/jenis-jenis-objek-wisata-alam-yang-perlu-anda-ketahui/), diakses 20 Oktober 2019.

Yoeti, Oka A. 1996. Pariwisata Berbasis Budaya, Masalah dan Solusinya. Jakarta: PT.Pradnya Paramita.

Pendit, Nyoman S. 1994. Ilmu Pariwisata: Sebuah Pengantar Perdana. Jakarta: PT. Pradnya Paramita.

Pitana, I. 2009. Pengantar Ilmu Pariwisata. Pengantar Ilmu Pariwisata. Yogyakarta: Andi.

Riwayatiningsih dan Purnaweni, Hartuti. 2017. Pemanfaatan Sistem Informasi Geografi dalam Pengembangan Pariwisata (Online), (Proceeding Biology Education Conference Vol. 14 (1): 154-161, Oktober 2017, diiakses Oktober 2019.

Sammeng, A. M. 2001. Cakrawala Pariwisata. Balai Pustaka.

Santosa, L.W. dan L. Muta'ali, 2014. Bentang Alam dan Bentang Budaya: Panduan Kuliah Kerja Lapangan Pengenalan Bentang Lahan. Yogyakarta: BPFG Universitas Gadjah Mada.

Saputro, E.P., F. Nurdiana, Y.T. Cahyono. 2006. Prospek Kepariwisatan dan Daya Tarik Daerah Tujuan Wisata. BENEFIT, Vol. 10 No 01, 2006. 
Siswantoro, H. 2012. Kajian Daya Dukung Lingkungan Wisata Alam Taman Wisata Grojogan Sewu Kabupaten Karanganyar. Tesis. Program Magister Ilmu Lingkungan Universitas Diponegoro, Semarang.

Soekadijo, R. G. 2000. Anatomi Pariwisata. Jakarta: Gramedia Pustaka Utama.

Soemarwoto, O. 2008. Ekologi, Lingkungan Hidup, dan Pembangunan. Jakarta: Penerbit Djambatan.

Suryadana, Liga M \& Octavia, Vanny. 2015. Pengantar Pemasaran Pariwisata. Bandung: Alfabeta.

Taryana, Didik. 2015. Pengaruh Formasi Geologi Terhadap Potensi Mata Air Di Kota Batu, (Online), (http://journal.um.ac.id/index.php/pendidikangeografi/article/view/5063/1813), diakses 20 Oktober 2019. 